The School Librarian's Role in Writing Instruction: Research, Perceptions, and Practice

By: April M. Dawkins and Karen W. Gavigan

Dawkins, A.M., \& Gavigan, K. W. (2017). The School Librarian's Role in Writing Instruction: Research, Perceptions, and Practice. International Journal of Libraries and Information Studies (LIBRI), 67(4), pp. 299-312. doi: 10.1515/libri-2017-0034.

Made available courtesy of Walter de Gruyter: http://dx.doi.org/10.1515/libri-2017-0034. The final publication is available at www.degruyter.com.

\begin{abstract}
***(C) 2017 De Gruyter. Reprinted with permission. No further reproduction is authorized without written permission from De Gruyter. ***
\end{abstract}

\begin{abstract}
:
The degree to which librarians are actively involved in developing the writing skills of students has primarily been studied in academic libraries (Bronshteyn and Baladad 2006, "Librarians as Writing Instructors: Using Paraphrasing Exercises to Teach Beginning Information Literacy Students.” The Journal of Academic Librarianship 32 (5):533-536; King 2012, "Essentials of Basic Writing Pedagogy for Librarians.” Community \& Junior College Libraries 18:55-66. Accessed March 20, 2016. doi:10.1080/02783915.2012.700211; Smith 2001, "Keeping Track: Librarians, Composition Instructors, and Student Writers Use the Research Journal.” Research Strategies 18:21-28) and has rarely been researched in terms of K-12 settings either in the United States or internationally. This paper examines the ways in which school library programs and school librarians contribute to the writing skills of K-12 students in South Carolina in the United States. A selective analysis of the findings is presented from Phase II of the South Carolina Association of School Librarian's (SCASL) 2014 School Library Impact Study, conducted by Keith Curry Lance and the RSL Research Group. The extent to which school librarians perceive their role in the teaching of writing in K-12 schools is examined, along with the perceptions of administrators and teachers. The results indicated that school librarians are less likely than other educators to assess their teaching of writing as excellent. Rather, administrators and teachers valued school librarians' contributions to the teaching of writing standards more than librarians did. In addition, the paper presents a review of the literature pertaining to the school librarian's contributions to the teaching of writing skills and offers suggestions for applying the findings of this research to practice.
\end{abstract}

Keywords: school librarian | writing | South Carolina Association of School Librarians | Impact study

Article:

***Note: Full text of article below 
April M. Dawkins* and Karen W. Gavigan

\section{The School Librarian's Role in Writing Instruction: Research, Perceptions, and Practice}

https://doi.org/10.1515/libri-2017-0034

Received May 10, 2017; accepted August 31, 2017

\begin{abstract}
The degree to which librarians are actively involved in developing the writing skills of students has primarily been studied in academic libraries (Bronshteyn and Baladad 2006, "Librarians as Writing Instructors: Using Paraphrasing Exercises to Teach Beginning Information Literacy Students." The Journal of Academic Librarianship 32 (5):533-536; King 2012, "Essentials of Basic Writing Pedagogy for Librarians." Community \& Junior College Libraries 18:55-66. Accessed March 20, 2016. doi:10.1080/ 02783915.2012.700211; Smith 2001, “Keeping Track: Librarians, Composition Instructors, and Student Writers Use the Research Journal.” Research Strategies 18:21-28) and has rarely been researched in terms of K-12 settings either in the United States or internationally. This paper examines the ways in which school library programs and school librarians contribute to the writing skills of K-12 students in South Carolina in the United States. A selective analysis of the findings is presented from Phase II of the South Carolina Association of School Librarian's (SCASL) 2014 School Library Impact Study, conducted by Keith Curry Lance and the RSL Research Group. The extent to which school librarians perceive their role in the teaching of writing in K-12 schools is examined, along with the perceptions of administrators and teachers. The results indicated that school librarians are less likely than other educators to assess their teaching of writing as excellent. Rather, administrators and teachers valued school librarians' contributions to the teaching of writing standards more than librarians did. In addition, the paper presents a review of the literature pertaining to the school librarian's contributions to the teaching of writing skills and offers suggestions for applying the findings of this research to practice.
\end{abstract}

Keywords: school librarian, writing, South Carolina Association of School Librarians, Impact study

*Corresponding author: April M. Dawkins, Library and Information Studies, University of North Carolina at Greensboro, Greensboro, NC, USA, E-mail: amdawkin@uncg.edu

Karen W. Gavigan, School of Library and Information Science, University of South Carolina, Columbia, SC, USA,

E-mail: kgavigan@mailbox.sc.edu

\section{Introduction}

In 1975, an article in Newsweek magazine, "Why Johnny Can't Write", proclaimed that there was a writing crisis among students in the United States. The author cited numerous examples of the declining writing scores of students in K-12 schools as well as colleges and universities. The article raised the alarm of the American public, with the statement that "the U.S. educational system is spawning a generation of semi-literates" (Sheils 1975, 58). Thirty-seven years later, in 2012, the U.S. Department of Education published the Nation's Report Card: Writing 2011, which shed new light on the fact that the majority of students in the United States are not proficient in writing. In fact, the Report Card revealed that only 24 percent of eighth and twelfth-grade students were Proficient in writing. According to the report, Proficient represents solid academic performance and students reaching this level have demonstrated competency over challenging subject matter. 54 percent of eighth-graders and 52 percent of twelfth-graders performed at the Basic level in writing in 2011, which denotes partial mastery of writing skills. Finally, only three percent of eighth- and twelfth-graders in 2011 performed at the Advanced level, which represents superior performance (National Center for Educational Statistics 2012).

As William Ellet, a former writing instructor at the Harvard Business School, stated about these troubling findings, “ ... from college on down ... nobody takes responsibility for writing instruction" (Holland 2013). What, if any, responsibility does the school librarian have in the writing achievement of his or her students? Although there are numerous studies examining the classroom teacher's role in writing instruction, there has been a dearth of studies examining the school librarian's responsibility in the process of teaching writing skills to students.

This paper presents selective findings from a school library impact study, conducted in the United States, regarding the role that school librarians play in the development of students' writing skills. In 2013, the Executive Board of the South Carolina Association of School Librarians (SCASL) commissioned a study of the impact of school libraries and school librarians in schools in South Carolina. The study was conducted by 
Dr. Keith Curry Lance, consulting with RSL Research Group president Marcia J. Rodney and vice president Bill Schwarz. Since 2000, Lance and his colleagues have conducted 16 school library impact studies in 12 states. As with these studies, data from the South Carolina impact study revealed that school library programs transform schools by contributing to student success. Unique to the South Carolina study, however, is the fact that it is the first study of its kind to document the contribution of school librarians to student success using test results for specific English Language Arts (ELA) and Writing standards.

This paper focuses on the writing components of Phase Two of the study. The data used for the second phase of the study was drawn from surveys of South Carolina school administrators, teachers and librarians, along with test results from the South Carolina Palmetto Assessment of State Standards (PASS) for elementary and middle school students (while high school educators are included in the overall survey analysis, their numbers were insufficient to examine the relationships between their survey responses and test results from the state's High School Assessment Program (HSAP) for high school students) (Lance et al. 2014).

Student performance on each of the writing components of the South Carolina PASS standards is classified into three groups:

- Showing weaknesses

- Needing additional services

- Showing strengths

Several school library characteristics were associated with these measures of student achievement for the writing component of the South Carolina study. The associations between library characteristics and student performance on writing PASS scores will be presented in this paper, along with figures representing the findings.

Just as there are a limited number of studies about the school librarian's role in the writing process, there is also a dearth of literature that examines what effective writing instruction from a school librarian should look like. The following section of this paper examines the literature from peer-review and practitioner journals, reports and international standards regarding this topic.

\section{Literature Review}

Surprisingly, there have been few studies conducted about the role of school librarians in writing instruction. The literature describes the partnership between English classrooms and research skills in the United States as they pertain to writing; however, there is little in the peer-review literature about writing pedagogy and school librarians. The limited number of studies that have been conducted on writing instruction in libraries pertains to writing as part of the research process itself, the prevention of plagiarism or the effectiveness of specific writing projects (Harada 2002; Heath 2015; Herring 2010; Hilbun 2015; McGregor and Streitenberger 1998; Williamson et al. 2007). However, there are numerous articles in the practitioner literature that examine the role of school librarians in the teaching of writing. For example, Bush advocates for the inclusion of "the silent literacy partner" in the school library in a 2009 article (40). Additionally, practitioner articles about writing have been published in the following U.S. journals: School Library Monthly, Teacher Librarian, Knowledge Quest, Library Media Connection, School Library Media Activities Monthly, and School Library Journal (Alexander 2015; Friese 2010; Garcia 2016; Haven 2010; Horan 2014; Kell 2009; Lowery 2005; Spence 2009; Thompson 2005; Van Vleet 2006).

\section{School Library Standards: Information Literacy and Writing}

Is writing instruction part of a school librarian's job? International and national standards used by school librarians support writing instruction as a major component of information literacy and either implicitly or explicitly address writing objectives. The recently updated definition of information literacy created by the Association of College and Research Libraries (ACRL) is that "Information literacy is the set of integrated abilities encompassing the reflective discovery of information, the understanding of how information is produced and valued, and the use of information in creating new knowledge and participating ethically in communities of learning." (Association of College and Research Libraries 2016, 3), a definition which hints at writing standards with its inclusion of "creating new knowledge". In order to create new knowledge, students need the ability to write. In a 2013 article, Farmer discusses the use of the term information literacy by the ACRL and American Association of School Librarians (AASL) in its 2007 Standards for the twenty-first Century Learner. She points out that the AASL standards only use the term "information literacy" once, but instead focus on the skills involved for learners to become information literate including the ability to 
create information, which implies that one of the skills learners need is the ability to write. Norgaard (2003, 2004), in a series of articles in Reference \& User Services Quarterly, clearly outlines the links between information literacy and writing. He believes librarians should "think of information literacy as "shaped" by writing - writing theory, writing instruction, and the very writing process itself” (2003, 125). In contrast, a study conducted in Israel by Ash-Argyle and Shoham examined the impact of school librarians on the information literacy of students; however, this focused on the reference skills instruction of the school librarians and makes no mention of writing (2014).

The International Society for Technology in Education (ISTE) standards are designed to assist librarians and teachers around the world in helping students to "engage and thrive in a connected and digital world" (International Society for Technology in Education 2016). Standard Six in this recently revised document contains the following standards, which implicitly relate to writing.

\section{Creative Communicator}

Students communicate clearly and express themselves creatively for a variety of purposes using the platforms, tools, styles, formats and digital media appropriate to their goals.

Students:

a. choose the appropriate platforms and tools for meeting the desired objectives of their creation or communication

b. create original works or responsibly repurpose or remix digital resources into new creations

c. communicate complex ideas clearly and effectively by creating or using a variety of digital objects such as visualizations, models or simulations

d. publish or present content that customizes the message and medium for their intended audiences

Similarly, in their 2016 School Library Guidelines, the School Library Standing Committee of the International Federation of library Associations and Institutions (IFLA) states that students "should be able to manage technology tools to access information and to communicate what they have learned" (IFLA School Libraries Section Standing Committee 2015, 45). While the term "writing" is not specifically used in the Guidelines, the use of the term "communicate" implies that students will use writing as a means for communicating what they have learned.

In addition to these two sets of international standards for students, school librarians in the United States use the American Association of School Librarians' (AASL's) Standards for the twenty-first Century Learner (2007). AASL's standards explicitly include writing in two of the standards:

- 2.1.6 Use the writing process, media and visual literacy, and technology skills to create products that express new understandings

- 3.1.3 Use writing and speaking skills to communicate new understandings effectively (ALA and AASL 2007, 5-6).

Writing is also implied in two other AASL standards:

- 1.1.3 Develop and refine a range of questions to frame the search for new understanding

- 1.1.7 Make sense of information gathered from diverse sources by identifying misconceptions, main and supporting ideas, conflicting information, and point of view or bias (ALA and AASL 2007, 4).

In addition, collaboration is a key role of school librarians: "The school library media program promotes collaboration among members of the learning community and encourages learners to be independent, lifelong users and producers of ideas and information" (ALA and AASL 2009, 20). This role as collaborator requires that school librarians become familiar with the standards of every curriculum area, such as science, social studies or technology. However, one of the most natural fits for school librarians is to collaborate with English Language Arts teachers. Standards for English Language Arts teachers usually contain a writing component, evident for example in the United States' Common Core Standards for English Language Arts (ELA) (Common Core State Standards Initiative 2010). The Common Core ELA Standards include four anchor strands, reading, writing, speaking and listening, with the emphasis in the writing strand placed on the ability to write based on evidence from text, rather than on creative writing skills. Evidence-based writing requires students to read critically and pull information from what they are reading (Common Core State Standards Initiative 2010), which would suggest that writing is a natural opportunity for school librarians to collaborate with classroom teachers.

\section{Writing in the Digital Age}

As indicated in the ISTE Standards for Students, digital skills are an essential component of students' ability to communicate. The teaching of writing skills has changed dramatically in the digital age: although digital 
technologies have made the process of creating and editing documents easier, these same technologies have "expanded options for writers and probably made writing, and learning to write, more complex" (Devoss, Hicks, and Eidman-Aadahl 2010, 21). A 2013 study related to this topic, The Impact of Digital Tools on Student Writing and How Writing is Taught in Schools, was conducted by the Pew Research Center's Internet \& American Life Project in collaboration with the College Board and the National Writing Project. The study interviewed 2,462 Advanced Placement (AP) and National Writing Project (NWP) teachers from middle and high schools in the United States and its territories. Among the findings was that only 15 percent of the teachers rated students as "excellent" or "very good" when it comes to appropriately citing content, with the majority rating students "fair" (37 percent) or "poor" (20 percent) in this area. A majority of these teachers indicated that they spend class time "discussing with students the concepts of citation and plagiarism" (88 percent) and "discussing with students the concepts of fair use and copyright” (75 percent) (Purcell, Buchanan, and Friedrich 2013, 5).

Since school librarians are considered by many to be experts on the topics of citations, plagiarism, fair use and copyright, the findings from this study offer a unique opportunity for librarians to collaborate with classroom teachers to teach information literacy skills that are essential components of the writing process.

\section{School Librarians and Writing}

Relative to the Pew study, two additional studies examined the context of plagiarism and writing skills; however, these studies examined it through the lens of school librarianship. McGregor and Streitenberger (1998) analyzed the results of two qualitative studies with high school students in Alberta and Texas that looked for plagiarism. Both authors attempted to determine if there was a relationship between the involvement of the school librarian and the incidence of plagiarism. They concluded that the librarian had a minimal role in both locations, which led to plagiarism and numerous citation errors, as well as that "For the benefit of all information users, perhaps librarians could initiate improved communication and collaboration designed to enhance learning. Modification of long-standing educational practices could lead to students' constructing a better model of both subject matter and information use" (12). Conducted in 2007, phase one of a study by Williamson, McGregor, Archibald and Sullivan conducted a large qualitative analysis of interviews and documents of school students and determined that the students were likely to copy and paste information. They found that despite being required to take notes and use information creatively for their assignments, the students found the "lure of copying and pasting ... hard to resist" (14).

A study by Harada (2002) moves beyond the mechanics of citations and plagiarism by examining a specific type of writing as part of the information search process: journal writing. Harada's study of elementary students in Hawaii looked at the impact of journal writing by students on the reflective practice of the school librarian. The purpose of the study was to see if the sharing of students' research journals with the teacher and school librarian would affect the teaching and engagement with students. While the purpose of the instruction was not specifically to improve writing skills but rather teach research skills, Harada concluded that "Their journal entries, however, were promising indications that they had taken the first steps in articulating new conceptions and new feelings about the information search process" (22). The ability to articulate ideas is an important part of information literacy and writing.

Another study that dealt with the use of writing as part of the research process is Herring's (2010) study. This study examined question formulation and the extent to which students, teachers and school librarians valued the development of questions as part of the research process. The study showed that most students, teachers and school librarians found question formulation a valuable skill, but many saw this value only in the context of information retrieval. Whether librarians are providing bibliographic instruction or teaching the research process, studies such as these support the concept that school librarians play an instrumental role in developing the writing skills of K-12 students, especially when collaborating with classroom teachers.

\section{Methodology for the South Carolina Study}

The South Carolina Association of School Librarian's (SCASL) 2014 School Library Impact Study was conducted by Keith Curry Lance and the RSL Research Group. This paper examines the second phase of the SCASL Impact Study which provided an analysis of the data collected in surveys of South Carolina school administrators, teachers and librarians as well as test results from the state's Palmetto Assessment of State Standards (PASS) for elementary and middle school students. Where possible, the 
accuracy of their assessments of library teaching of standards was checked against actual state test results by standard. Notably, South Carolina is the first state in which such a study has been conducted where this type of validity check has been possible, owing to the ready availability of standard-level test results. In February 2014, school librarians across South Carolina were asked to nominate themselves and other educators with whom they work or have worked as survey respondents for this study. In addition to themselves, these nominations included their principals, up to two other administrators and up to five teachers: 747 administrators were nominated for the survey and 273 (36.5 percent) responded, while 1094 teachers were nominated for the survey, with 917 (83.8 percent) responding. Elsewhere, 368 librarians volunteered for the survey and 321 (87.2 percent) responded.

The RSL Research Group conducted the analysis of the data. The findings of the Phase Two analysis are reported separately for each group, one each about administrators, teachers and librarians, with the inclusion of data charts. Each of those sections begins with a report of the survey results, followed by an analysis of:

- How the perceived importance of selected library policies and practices or the frequency of selected library-related activities is related to the assessment of library program teaching of standards

- How librarian roles desired by administrators, perceived by teachers and attributed to principals and teachers by librarians are related to the assessment of library program teaching of standards

- In turn, the extent to which educator assessments of library program teaching of standards are associated with actual state test results by standard

\section{Findings}

The South Carolina School Library Impact study is the first of its kind to document the contribution of school librarians to student success using Writing test scores and survey results. The findings from Phase Two of the study are presented below.

\section{Phase Two}

As documented in the AASL Standards for the 21st - Century Learner (2007), school librarians are expected to collaborate with teachers to teach skills and strategies that are relevant for students in the twenty-first century. This includes writing skills; however, findings from Phase Two of the South Carolina Study reveal that school librarians are less likely to value the role they play in the teaching of writing standards than administrators and classroom teachers do. Phase Two of the study is an analysis of data collected in surveys of South Carolina school administrators, teachers and librarians, as well as test results from the state's Palmetto Assessment of State Standards (PASS) for elementary and middle school students. Palmetto Assessment of State Standards (PASS) data indicated percentages of students not meeting and exceeding specific standards:

- For PASS Writing, there were overall results and separate results for two subsidiary standards, Content and Organization

- Percentages of students showing weaknesses and strengths in Writing were used

While high school educators are included in the overall survey analysis, their numbers were insufficient to examine the relationships between their survey responses and test results from the state's High School Assessment Program (HSAP) for high school students.

\section{Administrators}

747 administrators were nominated for the survey, and 273 (36.5 percent) responded. The administrators who responded to the survey were generous in their assessment of library program contributions to the teaching of Writing standards, with more than half who responded to the survey rating the librarian's teaching of Writing standards as excellent or good, specifically in the areas of Content and Organization (Figure 1). It appears these administrators recognized that the recent focus on librarians teaching students information literacy skills and other twenty-first century skills contributes to the teaching of writing as well.

\section{Flexible Scheduling}

For the purpose of the SCASL Study, flexible scheduling refers to a library policy of scheduling access to the library based on instructional need rather than a fixed schedule. As Figure 2 below indicates, administrators who believed that flexible scheduling of library access is essential were at least twice as likely as those who believed it to be less than essential to rate library teaching of Writing standards as excellent. 


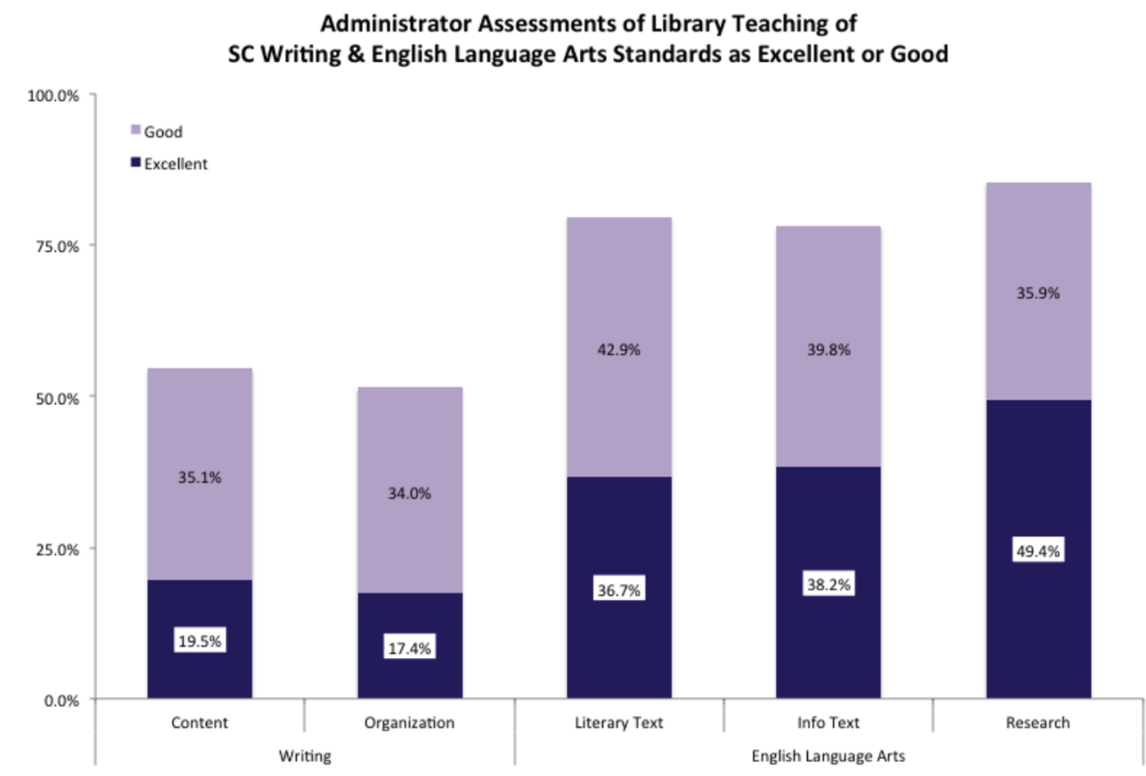

Administrator Assessments of Library Teaching of
SC Writing \& English Language Arts Standards as Excellent or Good

Figure 1: Administrator assessments of library teaching of writing and ELA standards.

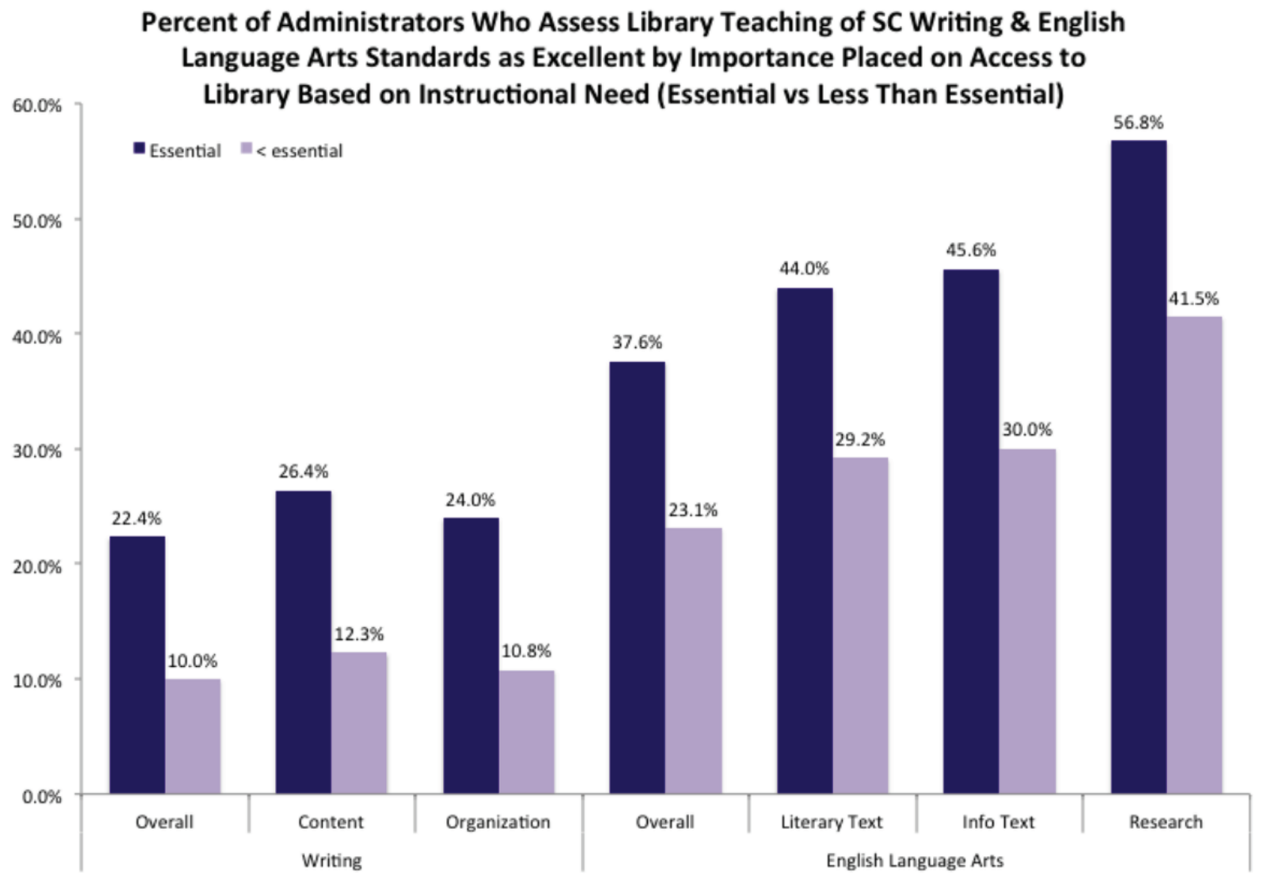

Percent of Administrators Who Assess Library Teaching of SC Writing \& English

Language Arts Standards as Excellent by Importance Placed on Access to

Ssential $=<$ essential

English Language Arts
Figure 2: Administrators' assessment of library teaching by importance placed on access to library.
In addition, administrators who most strongly endorsed flexible access policies and practices gave their librarians the highest marks of all for teaching Research skills.

Similar patterns in the administrators' assessments of library standards teaching were associated with the following three policies and practices:

- Librarian-teacher instructional collaboration

- Librarian-provided in-service professional development

- Regular meetings between principals and librarians
Administrators who regarded these elements as essential were twice as likely to assess library teaching of Writing as excellent, as demonstrated in the three charts below (Figures 3-5).

\section{Library Teaching of Standards}

The administrators' assessments of the contributions of their library programs to teaching standards were 


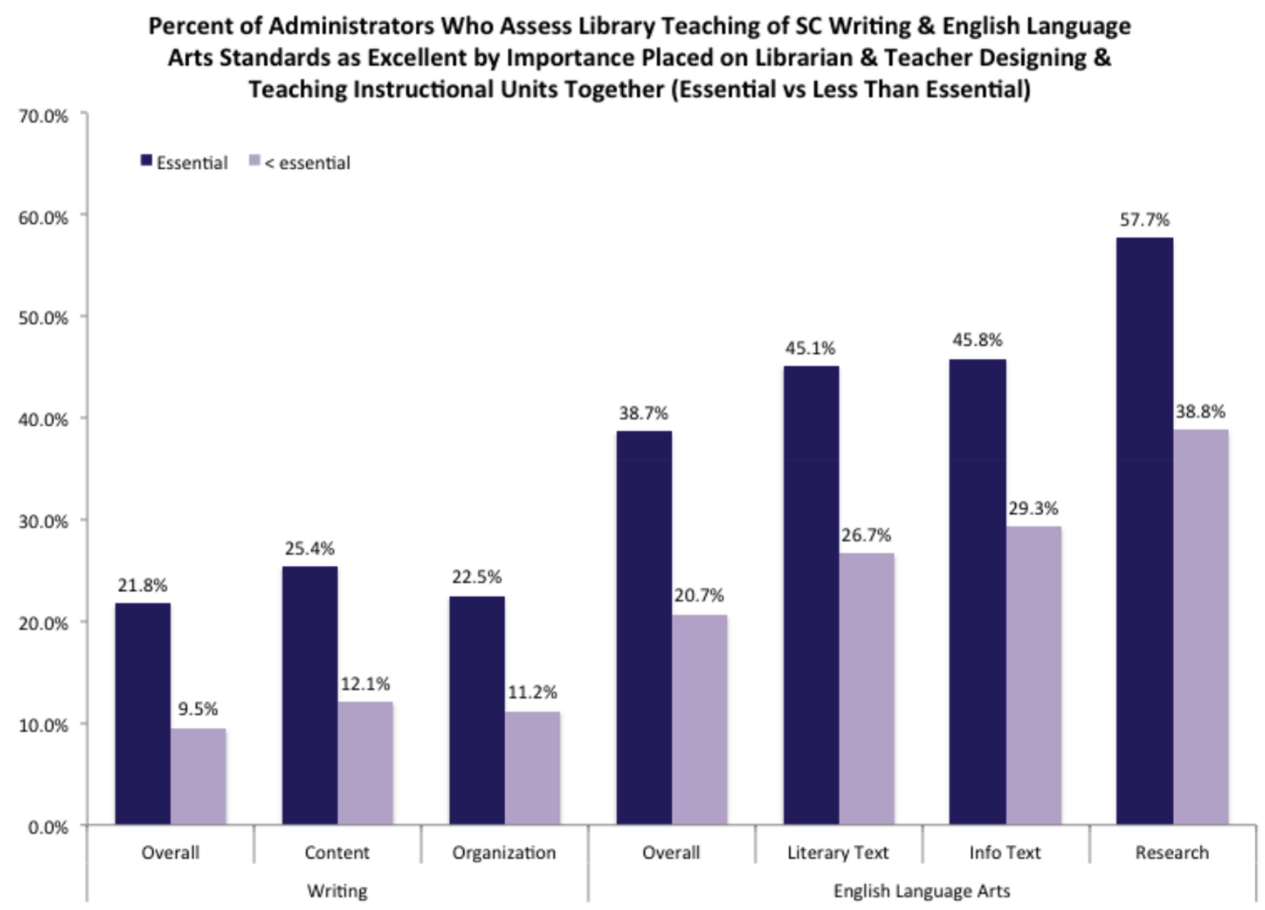

Figure 3: Librarian-teacher instructional collaboration.

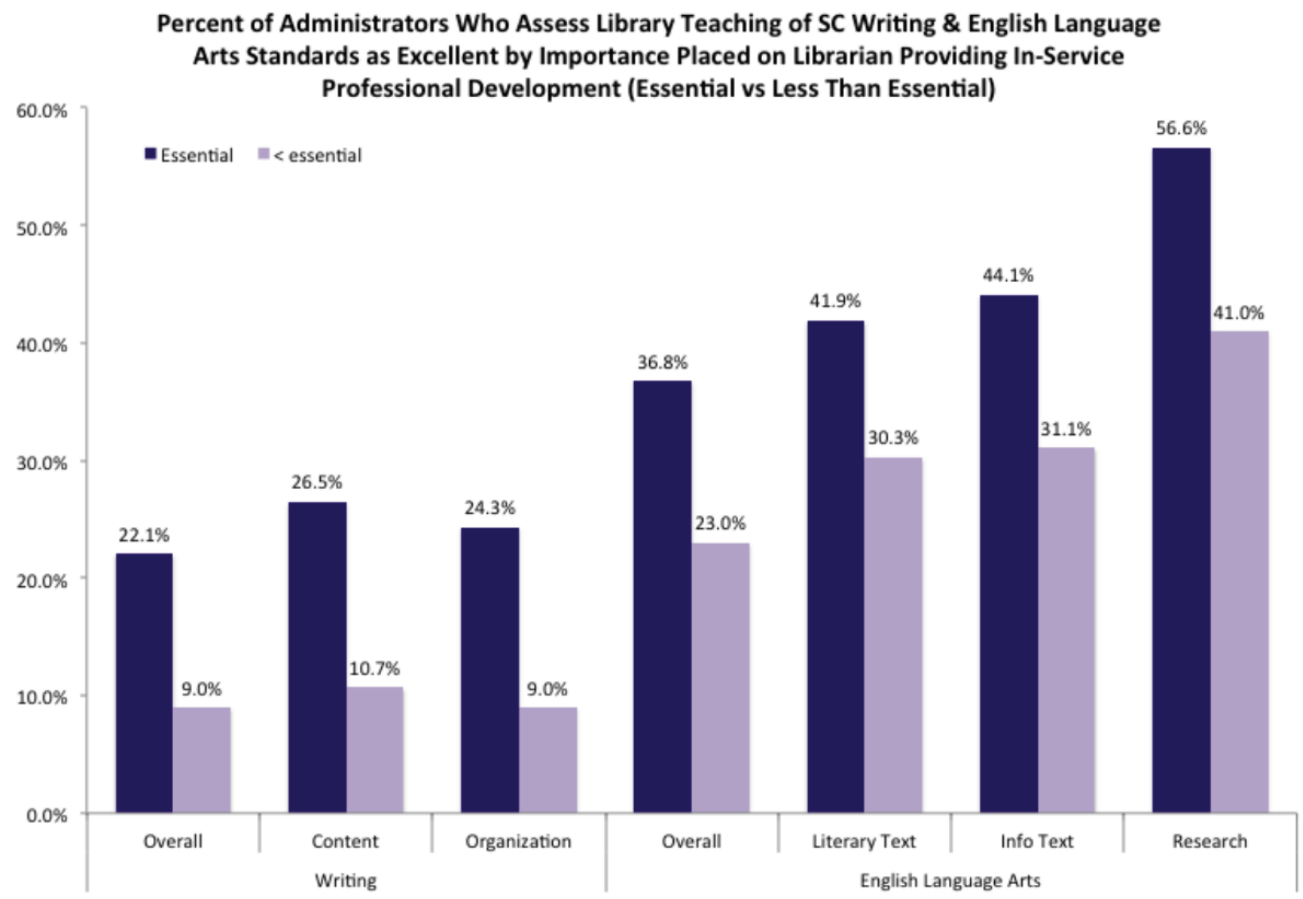

Figure 4: Librarian-provided in-service professional development.

consistent with PASS Writing results. For example, as indicated in Figure 6, where administrators assessed library teaching as excellent students were less likely to show weaknesses and more likely to show strengths in
Writing. These findings indicate that administrator assessments of the quality of library teaching of South Carolina standards tend to accurately reflect actual student performance. 


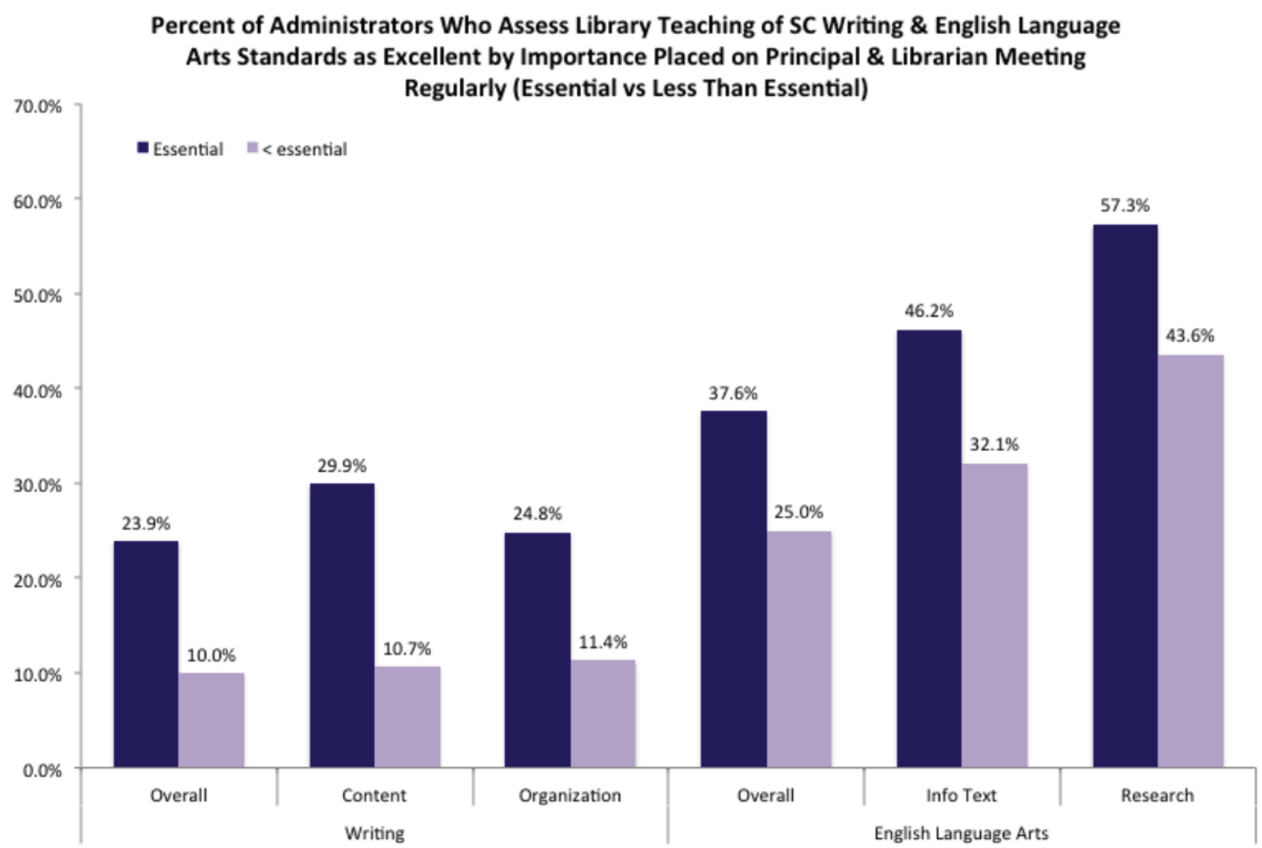

Figure 5: Regular meetings between principals and librarians. Percentages of SC Elementary \& Middle School Students Showing Strengths \& Weaknesses
on PASS Writing Standards by Administrator Assessment of Excellence of Library Teaching of Standards

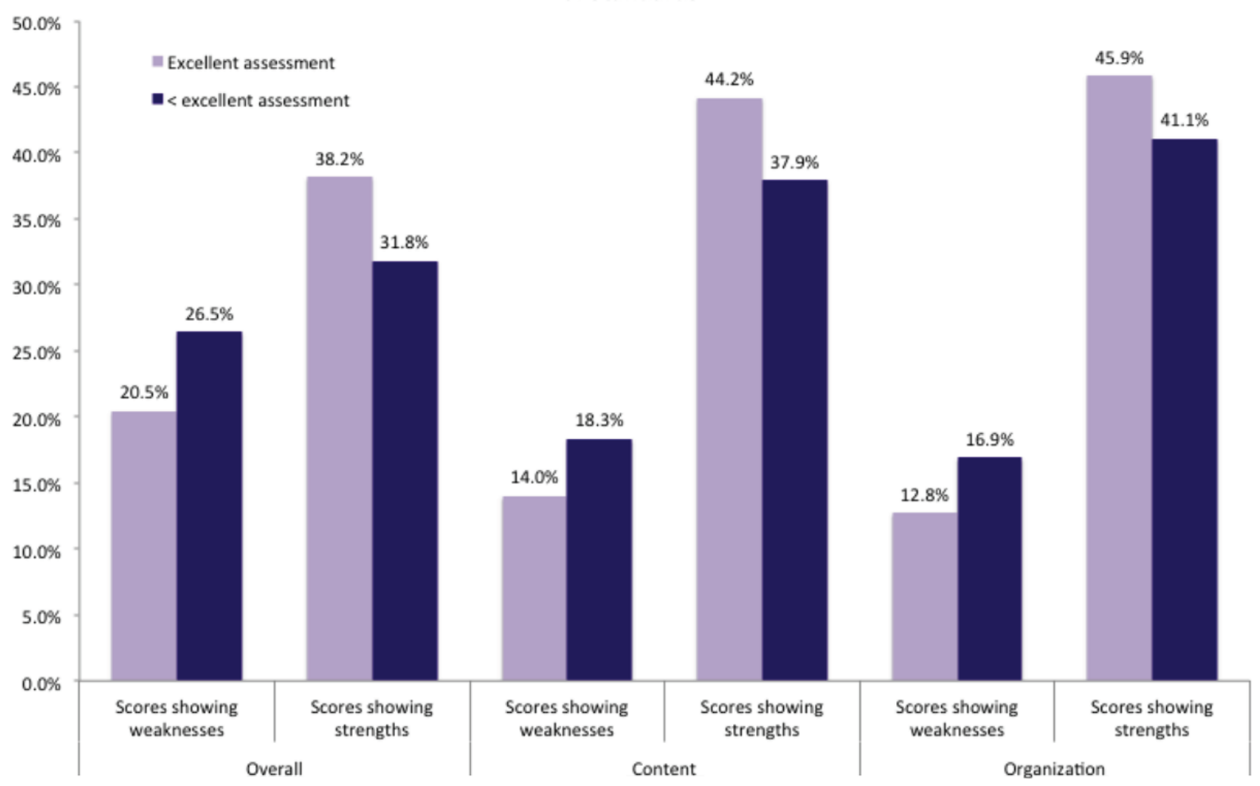

Figure 6: Strengths and weakness on writing standards by administrator assessment of library teaching as excellent.

\section{Teachers}

There were 1,094 teachers nominated for the survey and 917 (83.8 percent) responded. The perceptions of responding teachers indicate that they engage frequently in library-related activities and believed their school librarians played key instructional roles in their schools. Like the administrators who were surveyed, responding teachers were generous in their assessment of library program contributions to the teaching of Writing 
standards, specifically Content and Organization. Unsurprisingly, the place of libraries and librarians in teaching ELA standards was clearer to teachers but, notably, a sizeable proportion gave their librarians high marks for teaching Writing also (see Figure 7). As was the case with the administrators who participated in the survey, this could be because teachers are increasingly aware of the role that librarians play in teaching students information literacy skills.

In addition, teachers were more likely to assess library teaching standards as excellent if they reported perceiving their librarians playing the following roles:

- Tutor of At-Risk Students

- Curriculum Designer

- School Leader

- Co-Teacher

- In-Service Professional Development Provider

- Technology Instructor

- Teacher

- Technology Troubleshooter

- Instructional Resources Manager

- Reading Motivator (See Figure 8)

Although the rankings of these roles varied occasionally depending on the standard, teachers' perceptions of librarians playing these roles were associated with Writing standards, including Content and Organization.

There were 368 librarians volunteered for the survey and 321 (87.2 percent) responded. Compared to administrators and teachers, responding librarians' assessments of their teaching of South Carolina Writing and English
Language Arts (ELA) standards were dramatically different. Although they expressed a high level of confidence in their teaching of ELA standards, they were far less generous when assessing their teaching of Writing standards, specifically Content and Organization. As indicated in Figure 9, only around half of the responding librarians rated their teaching of Writing standards as excellent or good, while at least four out of five rated their teaching of ELA standards equally highly.

These findings suggest that, while librarians themselves clearly understand their contributions to teaching ELA standards, particularly Research, they are less clear, or perhaps just less confident, about their contributions to teaching Writing standards. This is surprising, given the focus in recent years on librarians teaching students to master information literacy and other twenty-first century learning skills that require excellence in Writing as well as ELA.

\section{Collaboration}

Findings from the survey revealed that librarians were dramatically more likely to rate their teaching of Writing standards as excellent if they reported collaborating with teachers on the design and delivery of instructional units at least weekly (Figure 10). Indeed, librarians who reported such frequent collaboration with teachers were two to five times more likely than less frequently collaborating librarians to rate their own teaching as excellent.

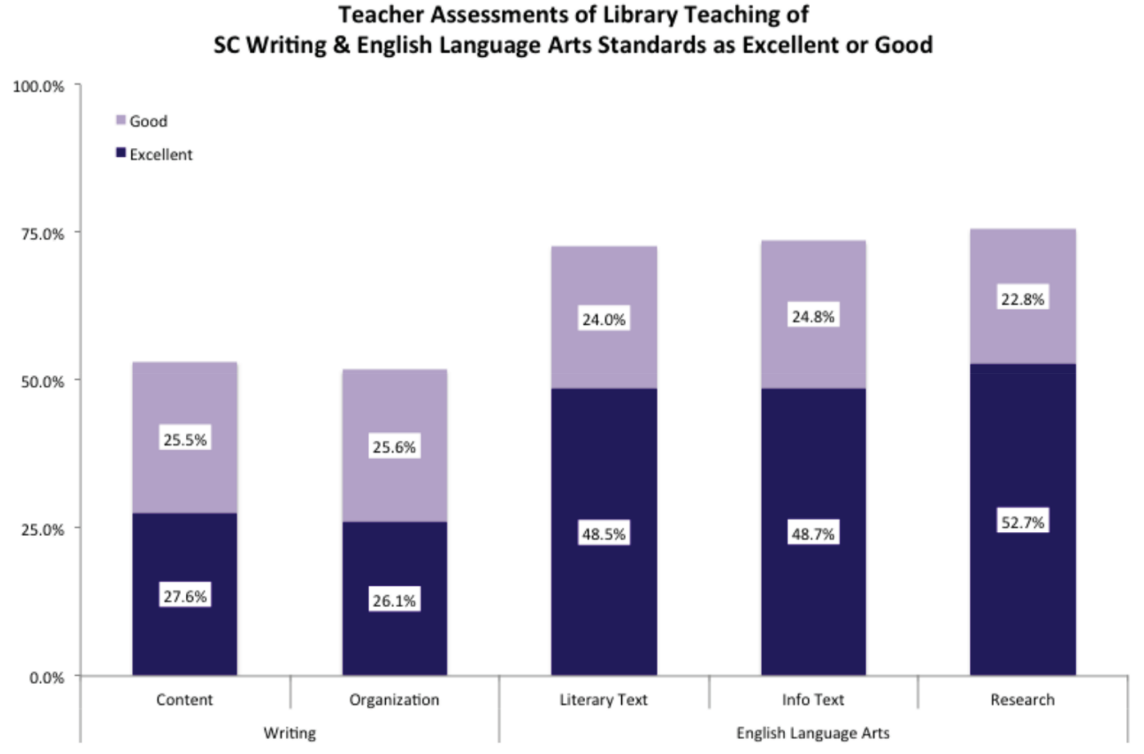

Figure 7: Teacher assessments of library teaching of standards. 


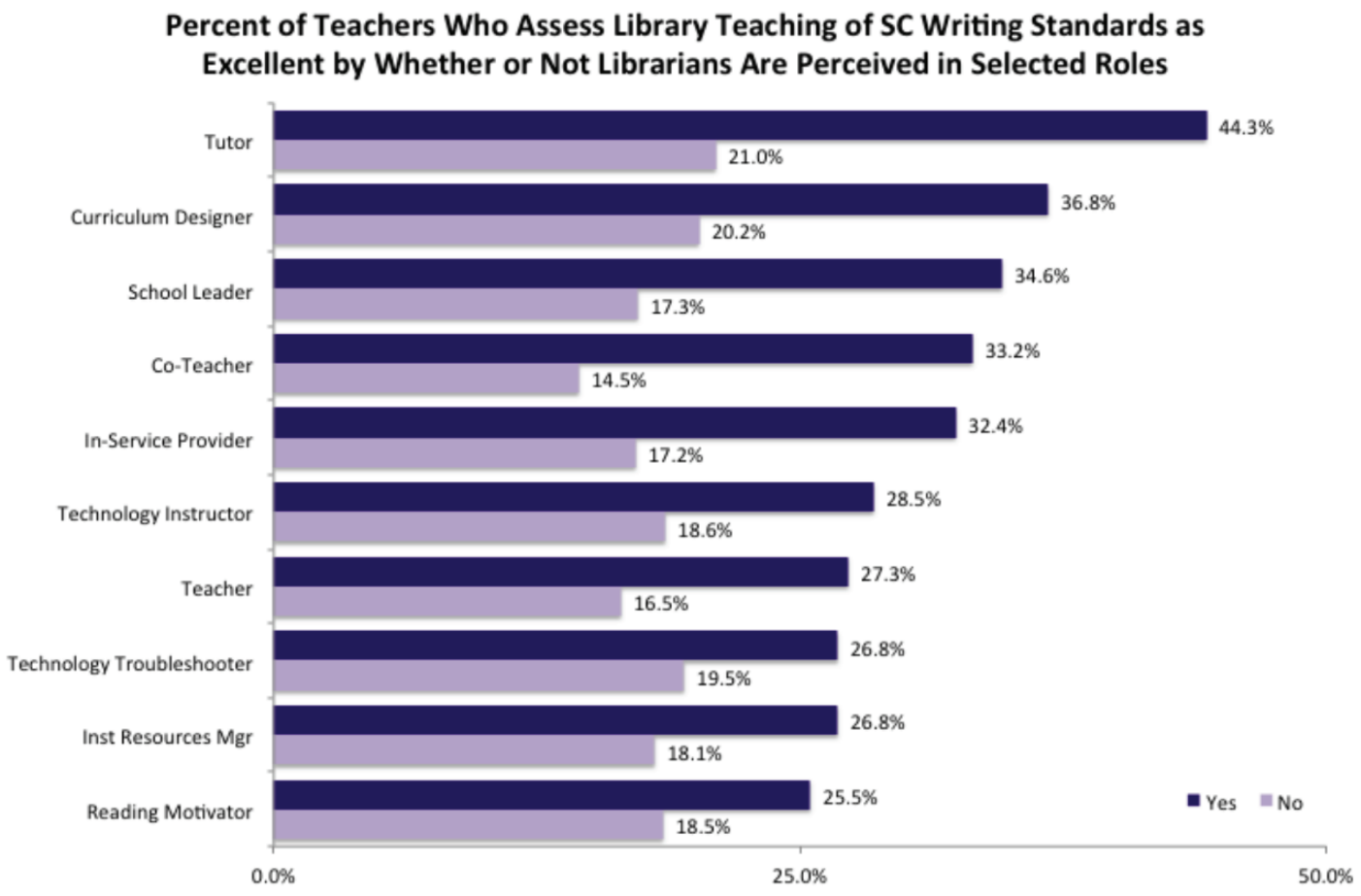

Figure 8: Teachers who assess library teaching as excellent based on role of librarians

Librarian Assessments of Library Teaching of

SC Writing \& English Language Arts Standards as Excellent or Good

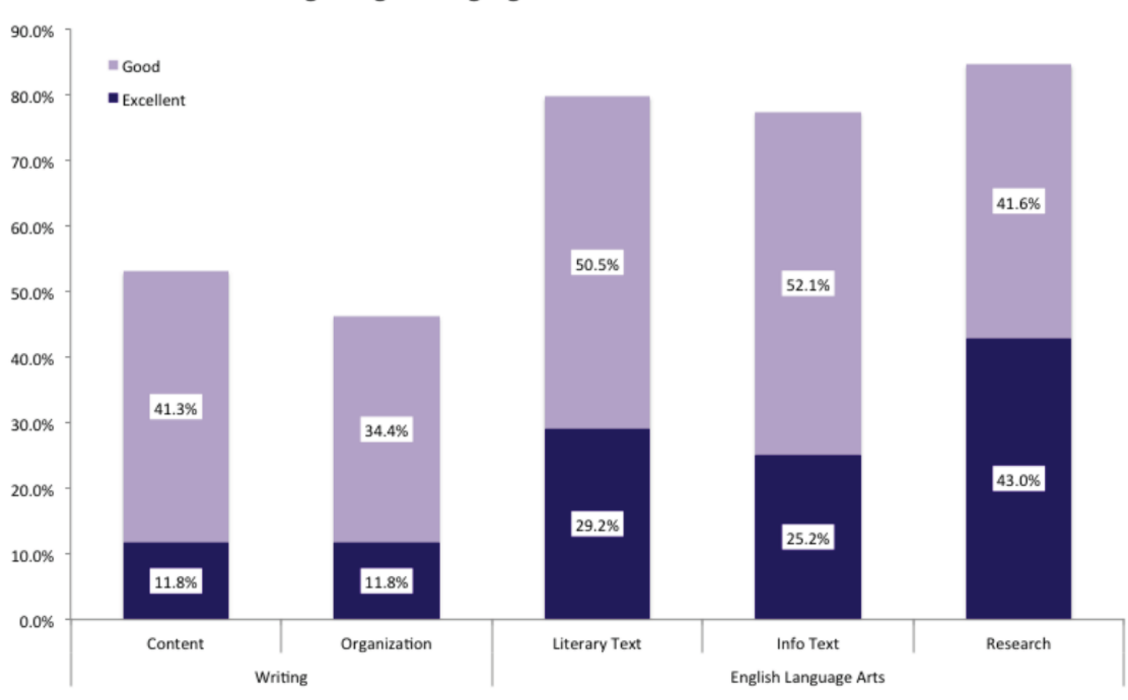

Figure 9: Librarian assessments of library teaching of standards.
Instructional collaboration is the only activity whose frequency reported by librarians correlated with their teaching self-assessments for Writing as well as ELA standards. The frequency of librarian reports of teaching and coteaching with teachers in their classrooms and helping teachers learn new information skills correlates only with their ELA standards self-assessments. Interestingly, librarians' reports of the frequency of flexibly scheduled visits are related only to ELA Research standards (with some apparent spillover effect on overall ELA standards). These findings suggest that South Carolina librarians either do not understand their impact on Writing 


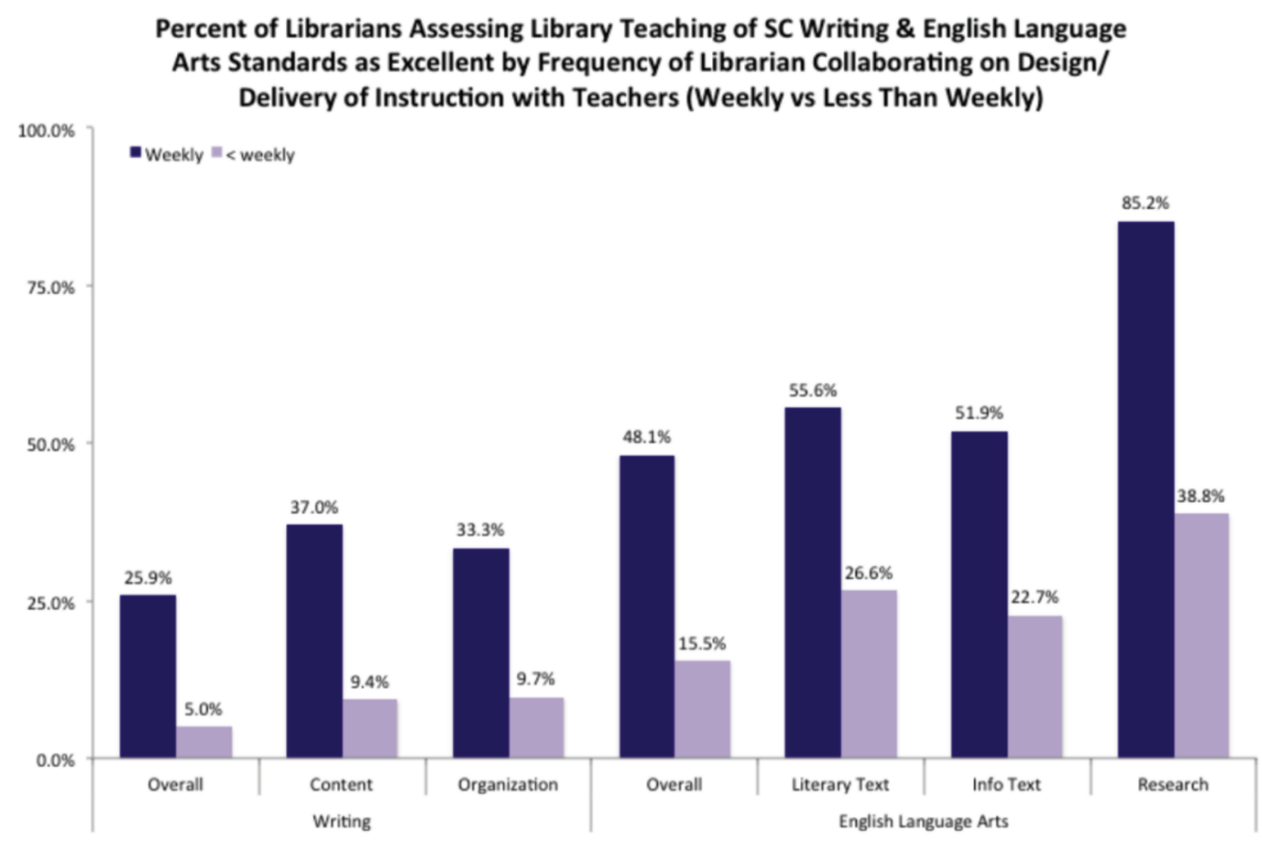

Figure 10: Librarians' assessment by frequency of collaboration.

performance in particular or, perhaps, actually are not having as great an impact on the teaching of those standards as is possible. Given the perceptions of administrators and teachers, the former seems more likely.

\section{Limitations and Recommendations}

One limitation of this study is that only data from one state in the southeastern area of the United States was used for the study. It is recommended that similar studies be conducted in additional states and countries however it would be challenging, if not impossible, to compare test data due to the differences in testing methods used around the world. An additional limitation was that the samples of administrators and teachers who received the surveys could not be randomly selected for this study. Out of necessity, the participants needed to be identified by their school librarians as administrators and teachers with whom they had worked. Since administrators and teachers were nominated by their school librarians and they voluntarily chose to participate in the survey, this may indicate that they already had a positive view of the value of the school librarian, causing them to respond favorably to the questions. Also, while the survey responses from teachers and librarians were quite high - more than eight respondents from every 10 nominations - the responses from administrators were less impressive, with only about a third of those nominated responding.

Finally, it is recommended that future studies include follow-up interviews with school librarians in order to shed light on the librarians' perceptions of their role in teaching writing. Such interviews might also reveal additional findings that could not be determined through the data from the SCASL Impact Study, such as some of the challenges that librarians face in regards to teaching writing in their schools.

\section{Discussion and Implications}

The findings from the writing aspects of Phase Two of the South Carolina Impact Study have several important implications for school librarians. First, the findings demonstrated that school administrators and teachers value the contributions of librarians in writing instruction. School librarians need to continue to advocate for their library programs and keep administrators cognizant of the many ways they are contributing to the academic success of their students. Teachers need to be reminded of the many ways that school librarians can collaborate with them for writing instruction.

The school librarians in this study undervalue the contributions they are making in writing instruction; however, they feel that they contribute a great deal to 
English Language Arts instruction. This finding implies that school librarians perceive English Language Arts to be primarily about reading literacy. School library preparation programs must move beyond the emphasis on creating the lifelong reader and move toward creating lifelong writers. For example, pre-service programs should consider including writing pedagogy as part of their curricula. Finally, the findings reveal that when the collaborations between teachers and librarians are deeper and more sustained, the school librarians perceive that their contribution to writing instruction has a greater impact. This highlights the need for pre-service school library programs to emphasize the instructional and collaborative role of school librarians.

\section{The Burning Question}

Why does it appear that many school librarians are unaware of the role that they can play in providing writing instruction? One possibility is that school librarians do not see themselves as having an impact because they may not be involved with formal writing instruction in their schools. Instead, they are contributing to writing instruction through the teaching of specific information literacy and research skills such as outlining, taking notes, question formation, citation and plagiarism issues, as well as thesis development. School librarians need to recognize that all of these skills are needed in order to help students become better writers. Another reason may be that some school librarians view the English Language Arts (ELA) teachers as the primary educators of reading and writing. School librarians may be underrating their role in teaching writing because they do not see themselves making as significant a contribution as language arts teachers.

\section{Summary and Conclusions}

Writing is one of the essential skills that students need to have in order to be college- and career-ready. The dire findings in the Nation's Report Card: Writing 2011 regarding the writing skills of U.S. students made it evident that schools need to take strong measures to ensure that all students are provided with the writing skills they need to further their education and/or to pursue future avocations and careers (National Center for Educational Statistics 2012). School librarians can play an essential role in helping to ensure that students are successful during and beyond their K-12 education. As instructional partners in their schools, they collaborate with classroom teachers to help students develop twenty-first century learning skills. The school librarian can play an influential role in the writing success of their students; however, findings from the South Carolina Impact Study reveal that school librarians do not value their writing instruction as much as other educators value school librarians' role in the writing process. Specifically, results from the surveys indicated that school librarians are less likely than other educators to assess their teaching of Writing standards as excellent. Rather, administrators and teachers valued library program contributions to the teaching of Writing standards more than librarians did. Due to the dearth of research on the topic of the school librarian's contributions to the teaching of writing skills, the findings from the SCASL study provide important implications for practice, pedagogy and research.

Understanding that there is a reluctance on the part of many school librarians to value their role in teaching writing as excellent can heighten an awareness of the need for additional training on writing pedagogy for pre- and in-service school librarians, as well as professional development opportunities for in-service school librarians. In addition, educators of school librarians can use the findings from this study as a reason to integrate writing pedagogy into their curricula for preservice school librarians. If school library faculty include the writing findings from the study and practical applications regarding the teaching of writing in their school library courses then pre-service school librarians will likely graduate with better writing efficacy than many practicing librarians. These future school librarians will also be better prepared to collaborate on writing instruction in their schools, with positive implications for improving the writing skills and achievement scores of their students. School librarians are uniquely qualified to integrate literacy instruction in all of its forms, including reading, writing and research. However, findings from the South Carolina School Library Impact Study revealed that school librarians are excessively modest when they assess their teaching of the Writing standards. This paper provides an argument for the need for additional training for in- and pre-service librarians to develop the skills needed to provide quality writing instruction in their schools. When school librarians collaborate with other educators to teach writing across the curriculum they can play a significant role in increasing the writing achievement of today's youth. 
Acknowledgements: "As the authors of the South Carolina study, Bill Schwarz, Marcia J. Rodney, and I thank our colleagues Karen Gavigan and April Dawkins for writing this article, and appreciate their using some of our report's language verbatim to ensure it is represented accurately.” Keith Curry Lance

\section{References}

Alexander, K. 2015. "What's Love Got to Do with It?: How to Get Teenagers Reading and Writing Poetry." School Library Journal 61 (11):35-37.

American Library Association and American Association of School Librarians. 2007. "Standards for the Twenty-first Century Learner." Accessed March 20, 2016. http://www.ala.org/aasl/ sites/ala.org.aasl/files/content/guidelinesandstandards/ learningstandards/AASL_Learning_Standards_2007.pdf.

American Library Association and American Association of School Librarians. 2009. Empowering Learners: Guidelines for School Library Media Programs. Chicago: American Library Association.

Ash-Argyle, R., and S. Shoham. 2014. "Professional Self-Efficacy and Role Perception of School Librarians and their Impact on the Development of Students' Information Literacy: An EvidenceBased Study." Journal of Information Literacy 8 (2):118-140. doi:10.11645/7.2.1894.

Association of College and Research Libraries. 2016. "Framework for Information Literacy for Higher Education.” Accessed April 5, 2016. http://www.ala.org/acrl/sites/ala.org.acrl/files/content/ issues/infolit/Framework_ILHE.pdf.

Bronshteyn, K., and R. Baladad. 2006. "Librarians as Writing Instructors: Using Paraphrasing Exercises to Teach Beginning Information Literacy Students." The Journal of Academic Librarianship 32 (5):533-536.

Bush, G. 2009. "This Writing Business: Nurturing the Literacy Habit in the School Library." School Library Monthly 26 (2): $38-40$.

Common Core State Standards Initiative. 2010. “Common Core State Standards for English Language Arts \& Literacy in History/Social Studies, Science, and Technical Subjects." Accessed March 20, 2016. http://www.corestandards.org/ ELA-Literacy?.

Devoss, D. N., T. Hicks, and E. Eidman-Aadahl. 2010. Because Digital Writing Matters: Improving Student Writing in Online and Multimedia Environments. San Francisco: Jossey-Bass.

Farmer, L. S. M. 2013. "How AASL Learning Standards Inform ACRL Information Literacy Standards." Communications in Information Literacy 7 (2):171-176.

Friese, B. 2010. "A Collection of Mentors: How the Library Program Can Support Writing Instruction." School Library Monthly 26 (7):17-19.

Garcia, A. 2016. "Remix.” School Library Journal 62 (5):40-43.

Harada, V. H. 2002. "Personalizing the Information Search Process: A Case Study of Journal Writing with Elementary-Age Students." School Library Media Research 5:2-25. Accessed March 20, 2016. http://www.ala.org/aasl/str.
Haven, K. 2010. "The Story of the Story: Research Support for the School Librarian's Role in Teaching Writing." School Library Monthly 26 (6):39-41.

Heath, R. A. 2015. "Toward Learner-Centred High School CurriculumBased Research: A Case Study." Journal of Librarianship and Information Science 47 (4):368-379. Accessed March 20, 2016. doi:10.1177/096100614532396.

Herring, J. E. 2010. "School Students, Question Formulation and Issues of Transfer: A Constructivist Grounded Analysis." Libri 60:218-229. Accessed March 20, 2016. doi:10.1515/ libr.2010.019.

Hilbun, J. 2015. "Find Poetry: Using Found Poems in School and Public Libraries to Enhance Student Creativity and Writing." The Journal of Research on Libraries and Young Adults 6:1-13. Accessed December 11, 2015. http://www.yalsa.ala.org/jrlya.

Holland, K. 2013. "Why Johnny Can't Write, and Why Employers are Mad.” NBC News. November 11. Accessed August 21, 2016. http://www.nbcnews.com/business/careers/why-johnny-cantwrite-why-employers-are-mad-f2D11577444.

Horan, T. 2014. "The School Library: The Perfect Place for a Writing Center." School Library Monthly 30 (8):5-7.

IFLA School Libraries Section Standing Committee. 2015. "IFLA School Library Guidelines.” Accessed May 10, 2017. https:// www.ifla.org/files/assets/school-libraries-resource-centers/ publications/ifla-school-library-guidelines.pdf.

International Society for Technology in Education. 2016. "ISTE Standards for Students." Accessed May 10, 2017. http://www. iste.org/standards/standards/for-students.

Kell, T. 2009. "Using Fan Fiction to Teach Critical Reading and Writing Skills." Teacher Librarian 36 (1):32-35.

King, R. 2012. "Essentials of Basic Writing Pedagogy for Librarians." Community \& Junior College Libraries 18:55-66. Accessed March 20, 2016. doi:10.1080/02783915.2012.700211.

Lance, K. C., B. Schwarz, and M. Rodney. 2014. "How Libraries Transform Schools by Contributing to Student Success: Evidence Linking South Carolina School Libraries and PASS \& HSAP Results." Phase II. Accessed August 12, 2017. https:// scasl.memberclicks.net/assets/phase\%202.pdf.

Lowery, J. 2005. "Information Literacy and Writing: Natural Partners in the Library Media Center." Knowledge Quest 34 (2):13-15.

McGregor, J. H., and D. C. Streitenberger. 1998. "Do Scribes Learn? Copying and Information Use." School Library Media Research 1:1-16. Accessed March 20, 2016. http://www.ala.org/aasl/slr.

National Center for Education Statistics, US Department of Education. (2012). "Writing 2011: National Assessment of Education Progress at Grades 8 and 12." Accessed November 1, 2015. http://nationsreportcard.gov.

Norgaard, R. 2003. "Writing Information Literacy: Contributions to a Concept." Reference \& User Services Quarterly 43 (2): 124-130.

Norgaard, R. 2004. "Writing Information Literacy in the Classroom: Pedagogical Enactments and Implications." Reference \& User Services Quarterly 43 (3):220-226.

Purcell, K., J. Buchanan, and L. Friedrich. 2013. "The Impact of Digital Tools on Student Writing and How It is Taught in Schools." Accessed May 10, 2017. http://www.pewinternet. org/files/old-media/Files/Reports/2013/PIP_NWP\%20Writing\% 20and\%20Tech.pdf. 
Sheils, M. 1975. “Why Johnny Can’t Write.” Newsweek 86:58-63. Smith, T. G. 2001. "Keeping Track: Librarians, Composition Instructors, and Student Writers Use the Research Journal." Research Strategies 18:21-28.

Spence, L. K. 2009. “Inquiry Based Writing Workshop.” Teacher Librarian 36 (1):23-27.

Thompson, H. M. 2005. "Connecting Information Literacy and Writing.” School Library Media Activities Monthly 21 (7):48-50.
Van Vleet, C. April/May 2006. "We're Writers, Too! Engaging Younger Students in the Writing Process." Library Media Connection 24 (7):42-43.

Williamson, K., J. McGregor, A. Archibald, and J. Sullivan. 2007. "Information Seeking and Use by Secondary Students: The Link between Good Practice and the Avoidance of Plagiarism." School Library Media Research 10:1-24. Accessed March 20, 2016. www.ala.org/aasl/slr. 